\title{
MIGRATION OF EXOTIC SPECIES OF AMMONITES DURING HIGHSTANDS OF SEA LEVEL
}

YOUNG, Keith, Dept. of Geological Sciences, University of Texas at Austin, Austin TX 78713-7909

In northeastern Chihuahua and Trans-Pecos Texas, in the early Late Albian zone of Hysteroceras varicosum occurs the Boeseites romeri (Haas) fauna with $B$. romeri (Hass), B. perarmata (Hass), B. aff. barbouri (Haas), B. cf. howelli (Haas), $B$. proteus (Haas), Prohysteroceras cf. P. hanhaense Haas, Elobiceras sp., and Dipoloceras (?) sp. B. perarmata has also been collected at Cerro Mercado, near Monclova, Coahuila. Haas originally described this fauna from Angola. Now, from rocks in the same zone in the Sierra Mojada, Coahuila, Mexico, there is a form related to if not identical with Hysteroceras famelicum Van Hoepen, also originally described from Angola and also from the zone of Hysteroceras varicosum.

These fossils are known only from southern North America and Angola; they have not been described from the European Tethys. In 1984 I suggested that during the highstand of sea level of the early Late Albian (Hysteroceras varicosum zone) these ammonites migrated from Angola to Mexico and Trans-Pecos Texas via an epeiric seaway extending across the sag between South America and Africa proposed by Kennedy and Cooper. This would be twelve to fifteen million years prior to an oceanic connection between the North and South Atlantic.

I would now ask, can similar epeiric seas and highstands of sea level explain the migration of successive European, Tethyan, Jurassic ammonite faunas down the Mozambique Channel and around the horn of Africa into the Neuquen Basin of Argentina before Africa and Antarctica separated, as proposed by Spath. 